02

\title{
Влияние полимерной матрицы на люминесцентные свойства композиций, допированных хелатами бора
}

\author{
() Е.В. Федоренко ${ }^{1}$, А.А. Хребтов ${ }^{2}$, А.Г. Мирочник ${ }^{1}$, П.С. Нефеедов ${ }^{2}$, Л.А. Лим ${ }^{2}$, \\ B.A. Реутов ${ }^{2}$, И.С. Павлов ${ }^{2}$, А.А. Сергеев ${ }^{3}$ \\ ${ }^{1}$ Институт химии Дальневосточного отделения РАН, \\ 690022 Владивосток, Россия \\ ${ }^{2}$ Дальневосточный федеральный университет, \\ 690091 Владивосток, Россия \\ ${ }^{3}$ Институт автоматики и процессов управления Дальневосточного отделения РАН, \\ 690041 Владивосток, Россия \\ e-mail: xrebtov_aa@dvfu.ru
}

Поступила в редакцию 24.12.2018 г.l

В окончательной редакции 24.12.2018 г.

Принята к публикации 07.05.2019 г.

Исследованы полимерные люминесцентные композиции на основе полистирола (ПС), поликарбоната (ПК) и полиметилметакрилата (ПММА), допированные дибензоилметанатом дифторида бора $\left(\mathrm{DBMBF}_{2}\right)$, антраценоилацетонатом дифторида бора $\left(\mathrm{Ant}_{\mathrm{AcBF}}\right)$ и их смесью. Максимальным квантовым выходом люминесценции обладает композиция на основе ПС. Выявлена роль ПС в повышении эффективности передачи энергии от донора $\left(\mathrm{DBMBF}_{2}\right)$ к акцептору $\left(\mathrm{AntAcBF}_{2}\right)$, что обусловлено образованием эксиплексов $\mathrm{DBMBF}_{2}$ с фенильными кольцами ПС.

Ключевые слова: $\beta$-дикетонаты дифторида бора, дибензоилметанат дифторида бора, полимеры, люминесценция, эксиплексы.

DOI: $10.21883 /$ OS.2019.09.48195.373-18

\section{Введение}

Одним из перспективных направлений применения полимерных люминесцентных композиций является разработка люминесцентных солнечных концентраторов (ЛСК), которые могут быть использованы в светопрозрачных конструкциях зданий (окнах, витражах) [1,2].

Разработка эффективных ЛСК непосредственно связана с выбором оптимальных люминофоров, к которым предьявляется значительный перечень требований, таких как высокий квантовый выход люминесценции (КВ); широкая полоса поглощения в области, где эффективность фотоэлектрических преобразователей (ФЭП) низка; высокий коэффициент поглощения; полоса излучения, совпадающая с областью максимальной спектральной чувствительности ФЭП; большой стоксов сдвиг для минимизации потерь в результате самопоглощения; фотостабильность в течение длительного периода времени [3].

$\beta$-дикетонаты дифторида бора являются перспективными люминофорами для этой цели, так как удовлетворяют вышеназванным требованиям [4-6], однако исследования, посвященные использованию данного класса соединений в ЛСК, практически отсутствуют.

На эффективность ЛСК значительное влияние также оказывает полимерная матрица. Матрица должна удовлетворять следующим условиям: хорошая растворимость люминофора, высокая фотостабильность в течение длительного периода времени, низкий коэффициент поглощения в широком спектральном диапазоне [3]. Этим условиям соответствуют следующие оптически прозрачные полимерные материалы: полистирол (ПС), полиметилметакрилат (ПММА), поликарбонат (ПК), а также сополимеры метилметакрилата (ММА) со стиролом и стирола с акрилонитрилом [7].

Ранее были исследованы полимерные композиции на основе ПС, допированного смесью дибензоилметаната дифторида бора $\left(\mathrm{DBMBF}_{2}\right)$ и антраценоилацетоната дифторида бора $\left(\mathrm{Ant}_{\mathrm{AcBF}}\right)$ (схема), которые характеризуются наличием сенсибилизированной люминесценции [8] и могут быть использованы для изготовления ЛСК [9]. В продолжение исследований в настоящей работе проведено сравнительное исследование люминесцентных свойств полимерных композиций на основе ПС, ПК и ПММА, допированных $\mathrm{DBMBF}_{2}$ и $\mathrm{AntAcBF}_{2}$.<smiles>F[PH]1(F)OCC(c2ccccc2)CC1c1ccccc1</smiles>

$\mathrm{DBMBF}_{2}$<smiles>CC1CCC(c2c3ccccc3cc3ccccc23)OB(F)O1</smiles>

$\mathrm{AntAcBF}_{2}$
Схема. 


\section{Экспериментальная часть}

$\mathrm{DBMBF}_{2}$ и AntAcBF 2 были получены по методикам [10] и [11] соответственно. ПС марки ПСМ-115 и ПК марки ПК-Л-10 были предварительно очищены методом переосаждения. ПММА был получен полимеризацией $10 \mathrm{~g}$ MМА в $40 \mathrm{ml}$ толуола при $80^{\circ} \mathrm{C}$ в течение $4 \mathrm{~h}$, в качестве инициатора использовали $0.01 \mathrm{~g}$ перекиси бензоила.

Полимерные пленки на основе ПС, ПК, ПММА, допированные 0.2 wt.\% AntAcBF $2,0.2$ wt.\% $\mathrm{DBMBF}_{2}$ и смесью люминофоров с мольным соотношением AntAcBF $2: \mathrm{DBMBF}_{2}$ 1:1 (концентрация AntAcBF 0.2 wt.\%), были получены методом пневмонапыления на стеклянную подложку размером $25 \times 76 \times 1 \mathrm{~mm}$ растворов $0.5 \mathrm{~g}$ ПС, ПК, ПММА и точных навесок AntAcBF 2 и $\mathrm{DBMBF}_{2}$ в $10 \mathrm{ml}$ дихлорэтана (квалификация „Химически чистый“). После высыхания пленки помещали в сушильный шкаф на $1 \mathrm{~h}$ при температуре $75^{\circ} \mathrm{C}$.

Спектры возбуждения люминесценции и люминесценции регистрировали на спектрофлуориметре Shimadzu RF5301. Время-разрешенные спектры и кинетика затухания люминесценции измерены на лазерном пикосекундном спектрофлуориметре FluoTime 200 (PicoQuant), источник PDL 800-B. Квантовые выходы люминесценции полимерных композиций измерены на спектрофлуориметре HoribaFluorolog 3 (Japan) методом интегрирующей сферы. Измерены полные КВ и КВ полосы эмиссии c $\lambda_{\text {рег }}=500 \mathrm{~nm}$.

\section{Результаты и обсуждение}

На рис. 1 представлены спектры возбуждения люминесценции и люминесценции пленок ПС, ПК и ПММА, содержащих смесь люминофоров с мольным

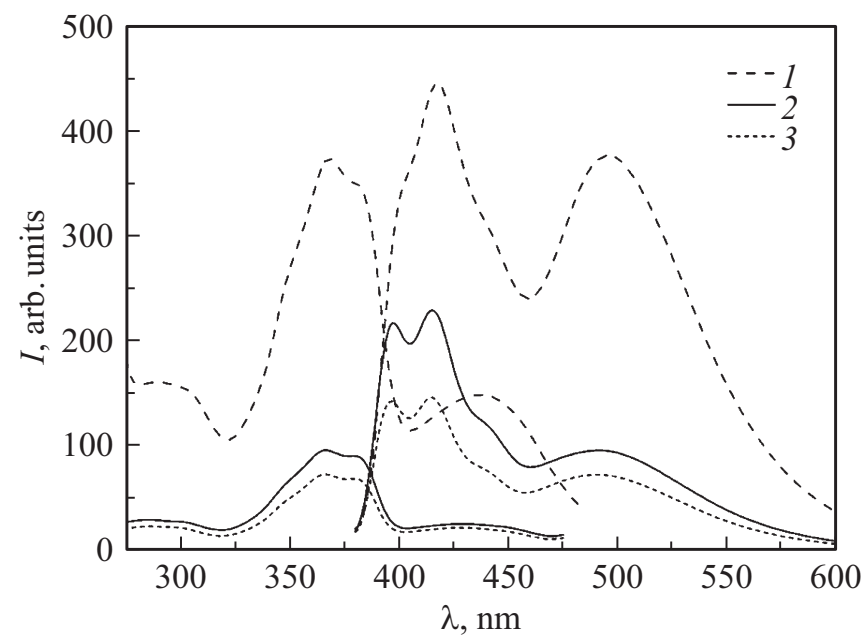

Рис. 1. Спектры возбуждения люминесценции (слева) и люминесценции (справа) пленок ПС $\left(\lambda_{\text {рег }}=500 \mathrm{~nm}\right.$, $\left.\lambda_{\text {возб }}=365 \mathrm{~nm}\right)(1)$, ПК $\left(\lambda_{\text {рег }}=490 \mathrm{~nm}, \lambda_{\text {возб }}=365 \mathrm{~nm}\right)$ (2) и ПММА $\left(\lambda_{\text {рег }}=490 \mathrm{~nm}, \lambda_{\text {возб }}=365 \mathrm{~nm}\right)(3)$ с мольным соотношением AntAcBF $: \mathrm{DBMBF}_{2} 1: 1$.

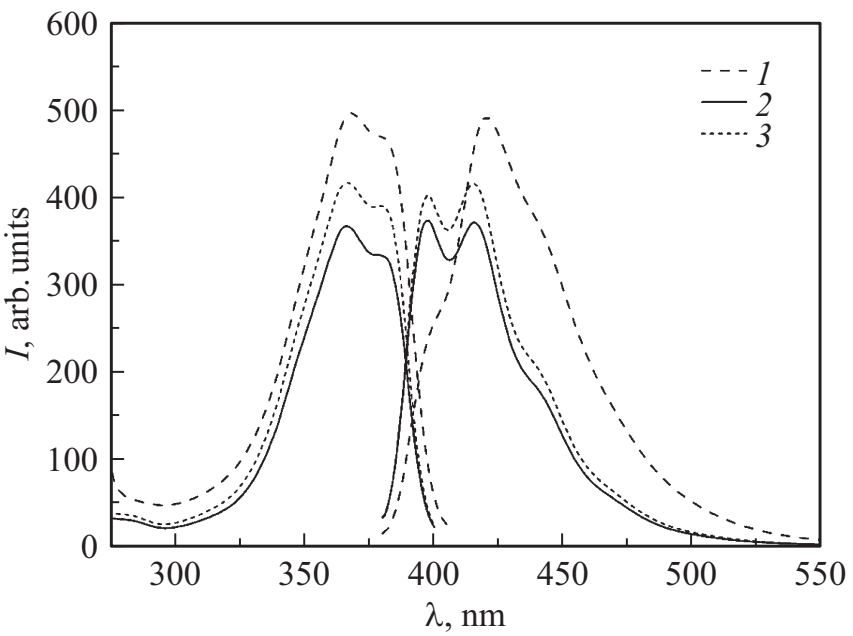

Рис. 2. Спектры возбуждения люминесценции (слева) и люминесценции (справа) пленок ПС $\left(\lambda_{\text {рег }}=420 \mathrm{~nm}\right.$, $\left.\lambda_{\text {возб }}=365 \mathrm{~nm}\right) \quad(1), \Pi К\left(\lambda_{\text {рег }}=415 \mathrm{~nm}, \lambda_{\text {возб }}=365 \mathrm{~nm}\right)$ и ПММА $\left(\lambda_{\text {рег }}=415 \mathrm{~nm}, \lambda_{\text {возб }}=365 \mathrm{~nm}\right)(3)$, допированных 0.2 wt.\% $\mathrm{DBMBF}_{2}$.

соотношением AntAcBF $2: \mathrm{DBMBF}_{2} 1: 1 . \mathrm{B}$ [8] показано, что в спектрах возбуждения люминесценции полимерной композиции на основе ПС полоса с максимумом $365 \mathrm{~nm}$ относится к возбуждению молекул $\mathrm{DBMBF}_{2}$, полоса с максимумом $440 \mathrm{~nm}$ - к возбуждению молекул $\mathrm{AntAcBF}_{2}$, а эмиссия $\mathrm{DBMBF}_{2}$ и $\mathrm{Ant} \mathrm{AcBF}_{2}$ характеризуется полосами 420 и $505 \mathrm{~nm}$ соответственно. В спектрах всех исследованных полимерных композиций наблюдаются полосы возбуждения люминесценции и люминесценции как $\mathrm{DBMBF}_{2}$, так и $\mathrm{AntAcBF}_{2}$. В отличие от ПС, где интенсивности полос люминесценции $\mathrm{DBMBF}_{2}$ и AntAcBF 2 близки, в пленках ПК и ПММА полоса люминесценции $\mathrm{DBMBF}_{2}$ значительно интенсивнее, чем AntAcBF 2 . При этом КВ пленки ПС (таблица) также имеет максимальное значение и более чем в 2 раза превышает КВ пленок ПК и ПММА.

Для объяснения наблюдаемого эффекта было проведено исследование поведения индивидуальных люминофоров в полимерных матрицах. Спектры люминесценции пленок ПС, ПК и ПММА, допированных 0.2 wt.\% AntAcBF 2 , имеют идентичную структуру, однако длинноволновая полоса возбуждения люминесценции $(440 \mathrm{~nm})$ и полоса люминесценции $(505 \mathrm{~nm})$ в ПС батохромно сдвинуты относительно соответствующих полос в спектрах AntAcBF 2 в ПК (430 и $498 \mathrm{~nm}$ ) и ПММА (430 и $496 \mathrm{~nm}$ ). КВ пленок ПС (таблица) имеют более высокие значения по сравнению с пленками ПК и ПММА.

На рис. 2 приведены спектры возбуждения люминесценции и люминесценции полимерных пленок, допированных $\mathrm{DBMBF}_{2}$. Спектры возбуждения люминесценции не зависят от материала матрицы, имеют колебательную структуру и соответствуют возбуждению мономерной люминесценции растворов $\mathrm{DBMBF}_{2}$ [12]. Однако в 
Значения КВ пленок на основе ПС, ПК, ПММА, допированных 0.2 wt.\% $\mathrm{DBMBF}_{2}, 0.2$ wt.\% AntAcBF 2 и смесью люминофоров с мольным соотношением AntAcBF $2: \mathrm{DBMBF}_{2} 1: 1$ (концентрация $\mathrm{AntAcBF}_{2} 0.2$ wt.\%)

\begin{tabular}{|c|c|c|c|c|}
\hline \multirow{2}{*}{ Образец } & \multicolumn{2}{|c|}{$\lambda_{\text {возб }}=365 \mathrm{~nm}$} & \multicolumn{2}{|c|}{$\lambda_{\text {возб }}=430 \mathrm{~nm}$} \\
\hline & Полный КВ, \% & КВ при 500 nm, \% & Полный КВ, \% & КВ при $500 \mathrm{~nm}, \%$ \\
\hline$\Pi C+\mathrm{AntAcBF}_{2}$ & 4.35 & 4.16 & 4.96 & 1.66 \\
\hline$\Pi К+\mathrm{AntAcBF}_{2}$ & 1.93 & 0.9 & 0.51 & 0.13 \\
\hline$\Pi \mathrm{MMA}+\mathrm{AntAcBF}_{2}$ & 3.43 & 1.72 & 2.5 & 0.21 \\
\hline$\Pi C+\mathrm{DBMBF}_{2}$ & 10.54 & - & - & - \\
\hline$\Pi К+\mathrm{DBMBF}_{2}$ & 6.26 & - & - & - \\
\hline$\Pi \mathrm{MMA}+\mathrm{DBMBF}_{2}$ & 11.65 & - & - & - \\
\hline$\Pi C+$ AntAcBF $_{2}: \mathrm{DBMBF}_{2} 1: 1$ & 13.81 & 8.97 & 5.14 & 4.65 \\
\hline$\Pi К+$ AntAcBF $_{2}: \mathrm{DBMBF}_{2} 1: 1$ & 5.86 & 2.12 & 0.31 & 0.1 \\
\hline$\Pi M M A+A^{A n t A c B F} 2: \mathrm{DBMBF}_{2} 1: 1$ & 6.35 & 2.2 & 1.36 & 0.47 \\
\hline
\end{tabular}

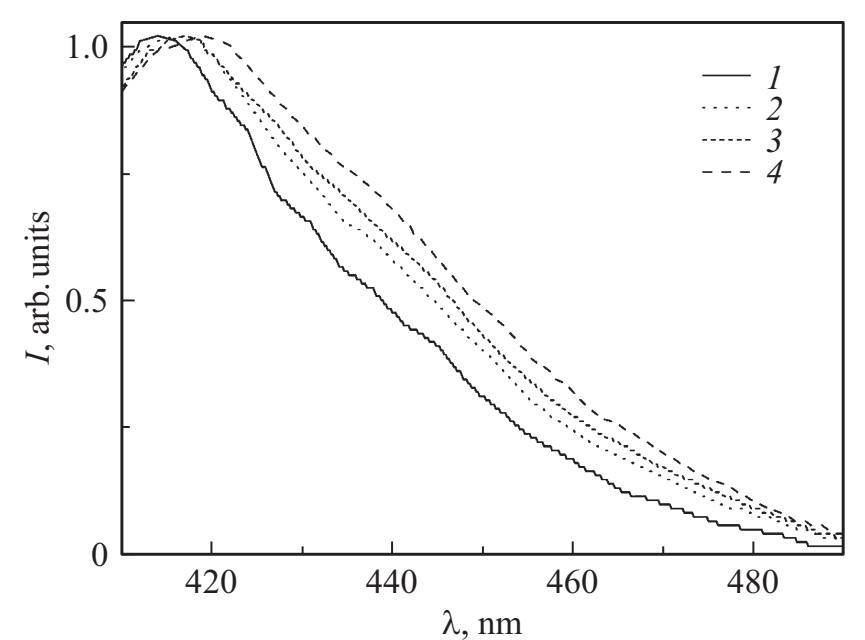

Рис. 3. Разрешенные во времени спектры люминесценции $\left(\lambda_{\text {возб }}=365 \mathrm{~nm}\right)$ пленки ПС, допированной $0.2 \mathrm{wt} . \% \mathrm{DBMBF}_{2}$ : время с момента возбуждения 0.2 (1), 0.5 (2), 0.7 (3), $1.6 \mathrm{~ns} \mathrm{(4).}$

спектрах люминесценции наблюдаются различия. Для пленок ПК и ПММА спектр люминесценции является зеркальным спектру возбуждения люминесценции и соответствует мономерной люминесценции разбавленных растворов $\mathrm{DBMBF}_{2}[12]$. Для пленки ПС зеркальной симметрии спектров возбуждения люминесценции и люминесценции не наблюдается, колебательная структура спектра не выражена. При этом полоса люминесценции пленки ПС $(420 \mathrm{~nm})$ батохромно сдвинута относительно длинноволновых полос люминесценции в пленках ПК и ПММА $(415 \mathrm{~nm})$.

Кинетика люминесценции $\mathrm{DBMBF}_{2}$ в пленках ПК и ПММА моноэкспоненциальна, время жизни возбужденного состояния составляет 1.4 и $1.6 \mathrm{~ns}$ соответственно. В пленке ПС кинетика люминесценции двухэкспоненциальна со временами жизни 3.5 и $1.4 \mathrm{~ns}$ (вклад 59.07 и $40.93 \%$ соответственно). Во времяразрешенных спектрах люминесценции пленки ПС, допированной $0.2 \mathrm{wt.} \%$
$\mathrm{DBMBF}_{2}$ (рис. 3), наблюдается смещение максимума люминесценции с 414 до $419 \mathrm{~nm}$ с течением времени.

Известно, что $\mathrm{DBMBF}_{2}$ с ароматическими соединениями образует эксиплексы $[13,14]$, для которых характерно батохромное смещение полосы люминесценции относительно мономерной люминесценции [15]. При этом эксиплексы характеризуются более яркой эмиссией по сравнению с мономерной люминесценцией $[14,16]$. Это согласуется с полученными в работе данными. Действительно, КВ композиции на основе ПС-матрицы, содержащей $\mathrm{AntAcBF}_{2}$ и $\mathrm{DBMBF}_{2}$, имеет большее значение по сравнению с композициями на основе ПК и ПММА. Более яркую эмиссию композиции на основе ПС можно объяснить образованием эксиплексов между фенильными кольцами полимера и молекулами $\mathrm{DBMBF}_{2}$. Это приводит к более интенсивному переносу энергии электронного возбуждения донор-акцептор и повышению КВ. Об эффективном переносе энергии возбуждения с уровней донора $\left(\mathrm{DBMBF}_{2}\right)$ на уровни акцеп-

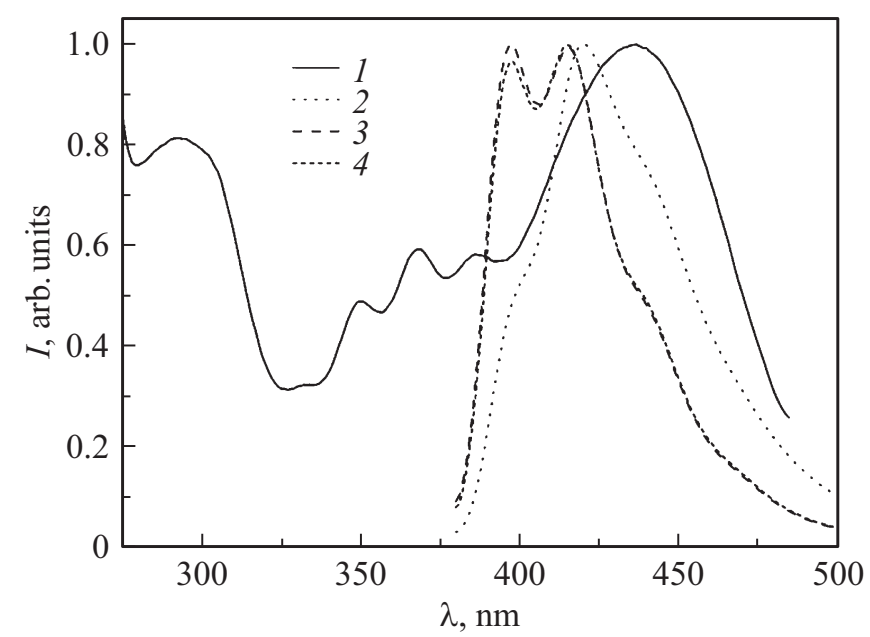

Рис. 4. Нормированные спектры возбуждения люминесценции пленки ПС $(1)$, допированной $0.2 \mathrm{wt} . \% \mathrm{Ant}_{\mathrm{AcBF}}$ $\left(\lambda_{\text {рег }}=500 \mathrm{~nm}\right)$, люминесценции пленок ПС $(2)$, ПК (3) и ПММА (4), допированных 0.2 wt.\% $\mathrm{DBMBF}_{2}\left(\lambda_{\text {возб }}=365 \mathrm{~nm}\right)$. 
тора $\left(\mathrm{Ant} \mathrm{AcBF}_{2}\right)$ свидетельствует факт существенного уменьшения КВ композиции при возбуждении в полосе акцептора (13.81\% - возбуждение донора; 5.14\% возбуждение акцептора) (таблица). При измерении КВ в полосе эмиссии акцептора $(500 \mathrm{~nm})$ наблюдается аналогичная картина $(8.97 \%$ - возбуждение донора; $4.65 \%$ возбуждение акцептора) (таблица). Следует отметить, что ПК также характеризуется наличием фенильных колец в своей структуре, однако по причине большей жесткости цепей ПК образование эксиплексов с $\mathrm{DBMBF}_{2}$ невозможно.

Кроме того, из рис. 4, на котором представлены спектры возбуждения люминесценции пленки ПС, допированной 0.2 wt.\% $\mathrm{AntAcBF}_{2}$, и люминесценции пленок ПС, ПК и ПММА, допированных 0.2 wt.\% $\mathrm{DBMBF}_{2}$, видно, что в ПС-матрице перекрывание полос люминесценции $\mathrm{DBMBF}_{2}$ и возбуждения люминесценции AntAcBF происходит в большей степени, чем в ПК и ПММА. Это приводит к лучшему переносу энергии от донора $\left(\mathrm{DBMBF}_{2}\right)$ к акцептору $\left(\mathrm{Ant} \mathrm{AcBF}_{2}\right)$ в ПС-матрице.

\section{Выводы}

Проведено исследование влияния природы полимерной матрицы на спектральные свойства полимерных люминесцентных композиций, допированных смесью люминофоров AntAcBF 2 и $\mathrm{DBMBF}_{2}$. Выявлена роль ПС в повышении эффективности передачи энергии от донора $\left(\mathrm{DBMBF}_{2}\right)$ к акцептору $\left(\mathrm{AntAcBF}_{2}\right)$, которая связана c образованием эксиплексов $\mathrm{DBMBF}_{2}$ с фенильными кольцами ПС, характеризующейся большей интенсивностью по сравнению с мономерной люминесценцией. Формирование эксиплексов в ПС-композиции приводит к существенному увеличению КВ по сравнению с композициями на основе матриц ПК и ПММА. Люминесцентные композиции на основе ПС могут быть предложены для создания ЛСК.

\section{Финансирование работы}

Исследование проведено при финансовой поддержке „Стипендии Гензо Шимадзу“.

\section{Список литературы}

[1] Fathi M., Abderrezek M., Djahli F. // Optik. 2017. V. 148. P. 14. doi 10.1016/j.ijleo.2017.08.127

[2] Zarcone R., Brocato M., Bernardoni P., Vincenzi D. // Energy Procedia. 2016. V. 91. P. 887. doi 10.1016/j.egypro.2016.06.255

[3] Klampaftis E., Ross D., McIntosh K.R., Richards B.S. // Sol. Energy Mater Sol. Cells. 2009. V. 93. N 8. P. 1182. doi 10.1016/j.solmat.2009.02.020

[4] Мирочник А.Г., Федоренко Е.В., Шлык Д.Х. // Изв. АН. Cep. хим. 2016. № 3. С. 806; Mirochnik A.G., Fedorenko E.V., Shlyk D.Kh. // Russ. Chem. Bull., Int. Ed., 2016. V. 65. N 3. P. 806.
[5] Карасев В.Е., Мирочник А.Г., Федоренко Е.В. Фотофизика и фотохимия b-дикетонатов дифторида бора. Владивосток: Дальнаука, 2006. 162 с.

[6] Chen P.-Z., Niu L.-Y., Chen Y.-Z., Yang Q.-Z. // Coord. Chem. Rev. 2017. V. 350. P. 196. doi 10.1016/j.ccr.2017.06.026

[7] Серова В.Н. Оптические и другие материалы на основе прозрачных полимеров. Казань: КГТУ, 2010. 540 с.

[8] Хребтов А.А., Федоренко Е.В., Лим Л.А., Реутов В.А. // Опт. и спектр. 2018. Т. 124. № 1. С. 71. doi 10.21883/OS.2018.01.45360.186-17; Khrebtov A.A., Fedorenko E.V., Lim L.A., Reutov V.A. // Opt. Spectrosc. 2018. V. 124. N 1. P. 68. doi 10.1134/S0030400X18010095

[9] Khrebtov A.A., Fedorenko E.V., Reutov V.A. // IOP Conf. Ser: Mater. Sci. Eng. 2017. V. 262. P. 12022. doi $10.1088 / 1757$ $899 X / 262 / 1 / 012022$

[10] Карасев В.Е., Коротких О.А. // Журн. неорган. химии. 1986. T. 31. № 4. C. 869.

[11] Fedorenko E.V., Bukvetskii B.V., Mirochnik A.G., Shlyk D.H., Tkacheva M.V., Karpenko A.A. // JOL. 2010. V. 130. № 5. P. 756. doi 10.1016/j.jlumin.2009.11.027.

[12] Fedorenko E.V., Mirochnik A.G., Lvov I.B., Vovna V.I. // Spectrochim. Acta Mol. Biomol. Spectrosc. 2014. V. 120. P. 119. doi 10.1016/j.saa.2013.10.016.

[13] Chow Y. L., Wang S.-S., Johansson C.I., Liu Z.-L. // J. Am. Chem. Soc. 1996. V. 118. P. 11725. doi 10.1021/ja9610444

[14] Chow Y.L., Johansson C.I., Liu Z.-L. // J. Phys. Chem. 1996. V. 100. P. 13381. doi 10.1021/jp961000h

[15] Chow Y.L., Johansson C.I. // J. Phys. Chem. 1995. V. 99. P. 17558. doi 10.1021/j100049a015

[16] Valat P., Wintgens V., Chow Y.L., Kossanyi J. // Can. J. Chem. 1995. V. 73. N 11. P. 1902. doi 10.1139/v95-235 